\title{
Histopathological and ultrastructural findings induced by heat-inactivated Lactobacillus plantarum and the culture supernatant on the intestinal mucosa of piglets: an ex vivo approach
}

\author{
[Achados histopatológicos e ultraestruturais induzidos por Lactobacillus plantarum inativado \\ pelo calor na mucosa intestinal de leitões: estudo ex-vivo] \\ L.G. Maidana, J. Gerez, F. Pinho, S. Garcia, A.P. Bracarense ${ }^{*}$ \\ Universidade Estadual de Londrina - Londrina, PR
}

\begin{abstract}
In the present study, histological, morphometrical and ultrastructural analysis were performed to investigate intestinal mucosa changes in piglets jejunal explants exposed to two concentration of heatinactivated Lactobacillus plantarum and their respective culture supernatants. Jejunal explants were incubated for 4 hours in DMEM culture medium with a) only culture medium (control group), b) heatinactivated Lactobacillus plantarum strain 1 - LP1 $\left(1.1 \times 10^{8} \mathrm{CFU} / \mathrm{ml}\right)$, c) heat-inactivated Lactobacillus plantarum strain 2 - LP2 $\left(2.0 \times 10^{9} \mathrm{CFU} / \mathrm{ml}\right)$, d) heat-inactivated Lactobacillus plantarum strain 1 culture supernatant (CS1), and e) heat-inactivated Lactobacillus plantarum strain2 culture supernatant (CS2). Explants exposed to heat-inactivated L. plantarum strain 1 and 2 showed multifocal to difuse villi atrophy, villi apical necrosis and enterocyte flattening. Morphological assessment revealed similar results with bacterial adhesion to mucus and intestinal epithelial cells and, morphometric analysis showed a decreased villi height compared to the control group. Alterations in explants treated with the culture supernatant of both strains include mild villi atrophy and mild enterocyte apical necrosis. Morphological assesment reveled numerous well delineated villi and, morphometric analysis showed a significant increase in villi height compared to the control group. In general, exposure to the culture supernatants improved the intestinal morphology.
\end{abstract}

Keywords: pigs, explants, intestine, probiotic

\section{RESUMO}

No presente estudo, foram realizadas análises histológica, morfométrica e ultraestrutural para investigar as alterações da mucosa intestinal em explantes jejunais de leitões expostos a duas cepas e concentrações de Lactobacillus plantarum inativado pelo calor e seus sobrenadantes de cultura. Os explantes jejunais foram incubados durante quatro horas, em meio de cultura DMEM com: a) meio de cultura (grupo controle); b) Lactobacillus plantarum, cepa $1-L P 1\left(1,1 \times 10^{8} \mathrm{CFU} / \mathrm{mL}\right)$; c) Lactobacillus plantarum, LP2 (2,0 x $\left.10^{9} \mathrm{CFU} / \mathrm{mL}\right)$; d) sobrenadante da cultura do Lactobacillus plantarum, cepa 1 (SC1); e e) sobrenadante da cultura do Lactobacillus plantarum, cepa 2 (SC2). Os explantes expostos às cepas 1 e 2 do L. plantarum inativado pelo calor mostraram atrofia difusa de vilosidades, necrose apical das vilosidades e achatamento de enterócitos. A avaliação morfológica revelou resultados semelhantes, com adesão bacteriana a muco e às células epiteliais intestinais, e a análise morfométrica mostrou uma diminuição da altura das vilosidades em relação ao grupo controle. Alterações nos explantes tratados com o sobrenadante da cultura de ambas as cepas caracterizaram-se por atrofia leve das vilosidades e necrose apical leve dos enterócitos. A avaliação morfológica revelou vilosidades bem delineadas, e a análise morfométrica mostrou um aumento significativo na altura das vilosidades em comparação ao grupo controle. Em geral, a exposição aos sobrenadantes da cultura melhora a morfologia intestinal.

Palavras-chave: suínos, explantes, intestino, probiótico

Recebido em 30 de agosto de 2017

Aceito em 17 de maio de 2018

*Autor para correspondência (corresponding author)

E-mail: ana.bracarense@pq.cnpq.br 


\section{INTRODUCTION}

Antimicrobials have been widely used in the diets of piglets to promote growth performance and reduce the incidence of diarrhea (Thacker, 2013; Yang et al., 2015a) Nevertheless, the resistance of pathogens to antimicrobials and the possibility of their residues in animal products resulted in an increasing interest in the use of alternatives to in-feed additives (Witte 2000, Salisbury et al., 2002). Additionally, as a result of cross-resistance, the European Union has completely banned the use of antimicrobials in animal feed to prevent diseases or promote growth (Yen et al., 2015).

Previous studies with lactic acid bacteria (LAB) in pigs suggest that probiotics provide a potential alternative to antimicrobial strategies (Yang et $a l ., 2015 b)$ and that certain strains of bacteria are effective in maintaining intestinal homeostasis. The effects of LAB include effective enhancement of the intestinal barrier function, modulation of the mucosal immune system, production of antimicrobials products, and alteration of the intestinal microbiota (Priyamvada et al., 2016).

Probiotics are defined as "live microorganisms which when administered in adequate amounts confer a health benefit on the host" (World Health Organization, 2001). However, there is evidence that probiotic preparations comprised of inactivated bacteria cells and their metabolites can also exert a biological response, similarly to that seen with live cells. Consequently, probiotics consisting of either live or dead cells or their metabolites may play an important role in health maintenance and disease avoidance in the host (Adams, 2010).

Stimulation of the immune response has been associated with the oral administration of both live and heat-killed LAB (Fujiwara et al., 2004; Sashihara et al., 2006). This effect is reflected by an increased lymphocyte proliferation and expression of IFN- $\gamma$ probably related to specific properties of the lactobacilli membrane (Lee et al., 2011). Heat inactivated cells of Enterococcus faecalis stimulated the gastrointestinal immune system in chickens (Sakai et al., 2006) and increased neutrophil phagocytosis in healthy dogs (Kanasugi et al., 1997). Furthermore, heat inactivated strains of Lactobacillus were able to modulate the immune response by stimulating the proliferation of murine splenocytes (Chuang et al., 2007). This probiotic paradox comprises a concept where both live and inactivated bacterial cells are capable of generating a biological response.

Bacterial metabolites may also have a favourable impact on the intestinal epithelial barrier function. Active factors produced during the bacterial growth are likely to be major contributors to the beneficial effects of probiotics, and active components in probiotic culture supernatant have been identified, including conjugated linoleic acids (Ewaschuk $e t$ al., 2006), short-chain fatty acids (Meimandipour et al., 2010), polyamines (Matsumoto et al., 2011), peptides (Fujiya et al., 2007), proteins (Yan et al., 2007) and, polyphosphates (Segawa et al., 2011).

Most of the previous studies concerning the effects of $\mathrm{LAB}$ and their metabolites on intestinal homeostasis were performed in in-vivo and invitro models. No available data were found regarding the interactions between $\mathrm{LAB}$ and the ex vivo model. Considering the need to broaden knowledge about the results of potential properties of $\mathrm{LAB}$, this study aimed to investigate the effects of the exposure of intestinal explants of pigs to heat inactivated Lactobacillus plantarum strains and their culture supernatant. To assay this, we performed histological, morphometrical and ultrastructural assessment using the jejunal explants culture technique. This investigation system allowed us to evaluate the intestinal tissue morphology, maintaining the complex patterns of differentiation seen in vivo.

\section{MATERIAL AND METHODS}

Six 24 days-old Landrace piglets were used to sample the explants. All animals were weaned at 21 days of age and then subjected to a standard diet in separate pens. Piglets were euthanized with intravenous injection of 1,3-diisopropilfenol (Propofol). The experimental procedures were conducted in accordance to the institutional (Universidade Estadual de Londrina, Brazil) Ethics Committee for Animal experimentation (number 11361.2014.30). 
Two strains of $L$. plantarum gently provided by the Food Science and Technology Laboratory (Universidade Estadual de Londrina, Brazil) were used in this study. Strain 1 was a $L$. plantarum American Type Culture Collection (ATCC 14917) and strain 2 was isolated from a sample of wheat grain from Paraná State, south Brazil. The isolation, identification and storage of LAB were described elsewhere (Franco et al., 2011). Briefly, strains of LAB were grown in Lactobacillus MRS broth (De Man, Rogosa and Sharpe media, HiMedia) and incubated at $37^{\circ} \mathrm{C}$ for $24 \mathrm{~h}$. Subsequently, $2 \mathrm{ml}$ of each culture was transferred to a flask containing $200 \mathrm{ml}$ of sterile MRS broth and incubated at $37^{\circ} \mathrm{C}$ for $24 \mathrm{~h}$. Microorganisms were counted by the double layer inoculation method in MRS agar plates after incubation at $37^{\circ} \mathrm{C}$ for $48 \mathrm{~h}$.

Lactic acid bacteria were heat inactivated by sterilization $\left(121^{\circ} \mathrm{C}\right.$ for 30min) (Shahin, 2007). After this procedure, the cell suspensions $(1.1 \mathrm{x}$ $10^{8}$ and $2.0 \times 10^{9} \mathrm{CFU} \mathrm{ml} l^{-1}$ of $\mathrm{LAB}$ for strain 1 and strain 2, respectively) were centrifuged $\left(3000 \mathrm{~g}, 10 \mathrm{~min}, 5^{\circ} \mathrm{C}\right)$. The resulting pellets and supernatant were separated and stored in microtubes tubes at $-20^{\circ} \mathrm{C}$ until the use. The inactivation of bacteria was confirmed by inoculation in MRS plates.

The procedures performed to obtain jejunal explants from piglets were previously described (Maidana et al., 2016). The explants were collected from middle jejunum with a biopsy punch $(8 \mathrm{~mm})$ and placed in six-well cell culture plates (3 explants/well) (Cellstar- Grenier bioone, São Paulo-Brazil) filled with $3 \mathrm{ml}$ of agar and containing Dulbecco's modified Eagle's medium (DMEM, Gibco- BRL Life Technologies, Carlsbad, CA) plus fetal bovine serum $(10 \%)$, glutamine $(0.2 \mathrm{ml} / \mathrm{L})$, gentamicin $(0.5 \mathrm{mg} / \mathrm{ml})$ and penicillin/streptomycin $(10 \mathrm{ml} / \mathrm{L})$. From each animal six explants were collected for each treatment.

The explants were incubated at $37^{\circ} \mathrm{C}$ for 4 hours with orbital shaking in the presence of the following treatments: control - only culture media (DMEM), culture media plus heat inactivated L. plantarum strain 1 (LP1), culture media plus heat inactivated L. plantarum strain 2 (LP2), culture media plus culture supernatant of strain 1 (CS1) and culture media plus culture supernatant of strain 2 (CS2). All the experimental procedures were performed in duplicated. Stored pellets were resuspended in the culture medium.

After the incubation period, explants were fixed in $10 \%$ buffered formalin solution, dehydrated in increasing alcohols and embedded in paraffin for histological analysis. Explants were sectioned at $5 \mu \mathrm{m}$ thickness parallel to the villi axis and stained with hematoxylin and eosin (HE), and mounted with coverslips. The histological changes were evaluated and a tissue morphological score was performed based on the intensity and severity of lesions. The criteria included in the tissue score were previously described (Maidana et al., 2016), Briefly, the criteria used were villi atrophy, number of villi, presence of cellular debris, interstitial edema and villi apical necrosis, and enterocyte morphology. The maximum score (39) indicates the overall integrity of the intestine. The lesion score was calculated by taking into account the degree of severity (severity factor) and the extent of each lesion (according to intensity or observed frequency, scored from 0 to 3 ). For each lesion, the score of the extent was multiplied by the severity factor.

The villi height was measured as the distance between the crypt mouth and the top of the villi randomly on ten villi. Ten intestinal crypts depth were also randomly measured. The morphometric analysis was performed from images taken with a Motic Image Plus 2.0 software (Motic Instruments, Richmond, Canada).

The explants exposed to the different treatments were submitted to scanning electron microscopy (SEM). Samples were fixed with $2 \%$ glutaraldehyde and $2 \%$ paraformaldehyde in $0.1 \mathrm{M}$ sodium cacodylate buffer $(\mathrm{pH} 7.4)$ at room temperature for $20 \mathrm{~h}$. The samples were then washed with sodium cacodylate buffer $(0.1 \mathrm{M}$, $\mathrm{pH} 7.2$ ) and treated with $1 \%$ osmium tetroxide in sodium cacodylate buffer for $1 \mathrm{~h}$, subjected to gradual dehydration in ethanol $(70,80,90$ and $100 \%$ ), and dried to the critical point (CPD 030 Critical Point BALTEC Dryer, Leica Microsystems, Liechtenstein). After drying, the samples were glued on stubs using carbon tape and coated with gold (Sputter Coater BALTEC SDC 050, Leica Microsystems, Liechtenstein). 
The explants were analyzed using a scanning electron microscope (FEI Quanta 200).

The data used for statistical analysis were represented as means with their standard deviation. The experimental design used in the present study was entirely randomized with 30 repetitions for each treatment (each explant representing one repetition). Oneway analysis of variance (ANOVA) followed by multiple comparison procedure (Tukey test) was used for statistical analysis. Normality and homogenity of total score and morphometric means were attended. Differences were considered statistically significant at $\mathrm{P} \leq 0.05$. Statistical analysis were performed with free software Action 2.3 (Campinas, SP, Brazil).

\section{RESULTS AND DISCUSSION}

After four hours of incubation, untreated explants (control group) presented mild villi atrophy and edema of lamina propria (Figure 1A), whereas explants exposed to LP1 and LP2 showed multifocal to difuse villi atrophy, villi apical necrosis and enterocyte flattening (Figure 1B, Figure 1C). Histological changes were more severe in explants exposed to LP1 compared to LP2. The main alterations in explants treated with CS1 and CS2 were mild villi atrophy and mild enterocyte apical necrosis. In general, the histological aspect of the CS1 and CS2 groups were similar or even better than the control explants.

The mean morphological score was of $35 \pm 4.15$, $27.75 \pm 4.62, \quad 29.17 \pm 2.12, \quad 34.78 \pm 3.69$ and $38 \pm 1.19$ for the control, LP1, LP2, CS1 and CS2, respectively. A significant decrease in the score was observed in explants exposed to both strains of heat inactivated lactobacilli $(\mathrm{P}=0.01$ and 0.05 for LP1 and LP2, respectively) when compared to control group. On the other hand, explants submitted to CS1 and CS2 remained statistically similar to the control group and showed a significant increase in the morphological score when compared to explants exposed to LP1 and LP2 (Figure 1F).

The morphometric analysis showed a significant increase in villi height in explants treated with both $L$. plantarum culture supernatant $(\mathrm{P} \leq 0.05)$ compared to the control group and to both strains of the heat inactivated bacteria (Figure 2). The mean villi height of the control group was $124.67 \pm 37.15 \mu \mathrm{m}$, while the group treated with $\mathrm{CS} 1$ and CS2 was 184.26 \pm 30.45 and $216.26 \pm 25.34 \mu \mathrm{m}$, respectively. The mean villi height of explants exposed to LP1 and LP2 was $114.37 \pm 21.89$ and $108.13 \pm 24.54 \mu \mathrm{m}$, respectively.

Crypt depth mean in untreated explants was 137.27 \pm 5.32 , whereas for LP1, LP2, CS1 and CS2 was $140.72 \pm 8.35, \quad 138.27 \pm 4.60$, $150.24 \pm 3.75$ and $148.35 \pm 4.79 \mu \mathrm{m}$, respectively.

A significant increase in crypt depth was observed in explants submitted CS1 when compared to the control group (Figure 2).

The scanning electron micrographs of the apical membranes of control jejunal explants showed numerous finger shaped, well delineated villi with goblet cells at surface (Figure 3A-3B); heat inactivated LP1 and LP2 showed mild atrophy (Figure 3C) and bacterial adherence to the villi (Figure 3D). CSs groups showed well defined villi in intestinal surface (Figure $3 \mathrm{E}$ ) and mucin covering villi surface (Figure $3 F$ ). 


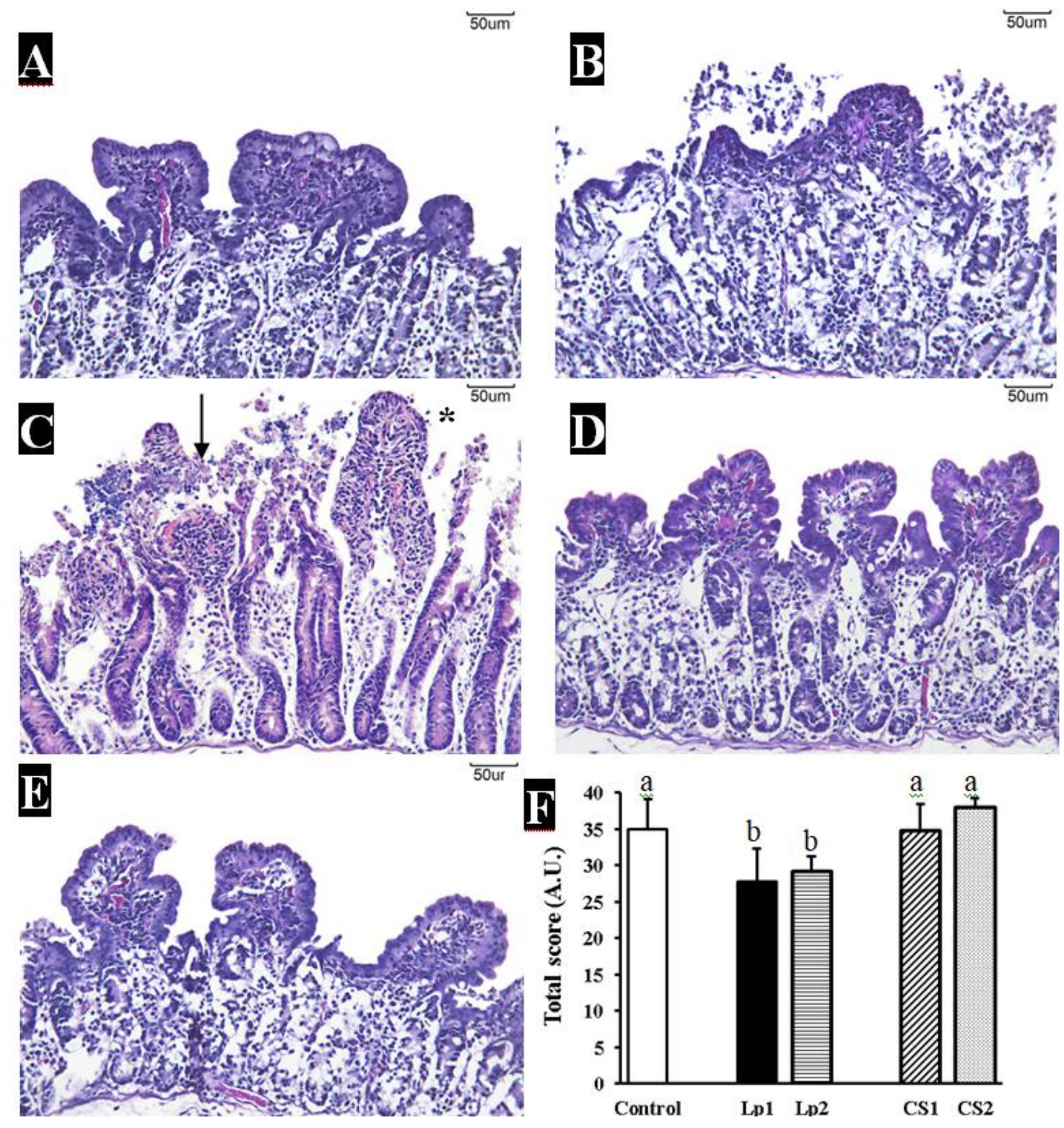

Figure 1. Effects of heat-inactivated L. plantarumand the culture supernatant exposure on jejunal explants of pigs. (A) Control explant showing mild edema of the lamina propria. Bar 50 $\mu \mathrm{m}$ (B) Explant exposed to LP1. Villi apical necrosis, cell debris, enterocyte flattening. Bar 50 $\mu \mathrm{m}$ (C) Explant exposed to LP2. Villi atrophy and diffuse enterocyte flattening (*), bacteria adhesion (arrow). Bar 50 $\mu \mathrm{m}$ (D and E) Explants exposed to culture supernatant of strain 1 (D) and strain 2 (E). Mild edema of the lamina propria and normal columnar enterocytes. Bar $50 \mu \mathrm{m}$ (F) Morphological score of the explants exposed to different treatments. Values are mean height and depth $(\mu \mathrm{m})$. Values are means with standard deviation of the mean represented by vertical bars (n 6 animals). Means with unlike letters (a, b) differ significantly by Tukey's test ( $\mathrm{p} \leq 0.05)$.LP1- heat-inactivated $L$. plantarumstrain 1, LP2- heat-inactivated L. plantarumstrain 2, CS1- culture supernatant of heat-inactivated L. plantarumstrain 1, CS2- culture supernatant of heat-inactivated L. plantarum strain 2 and arbitrary unit (A.U.). 


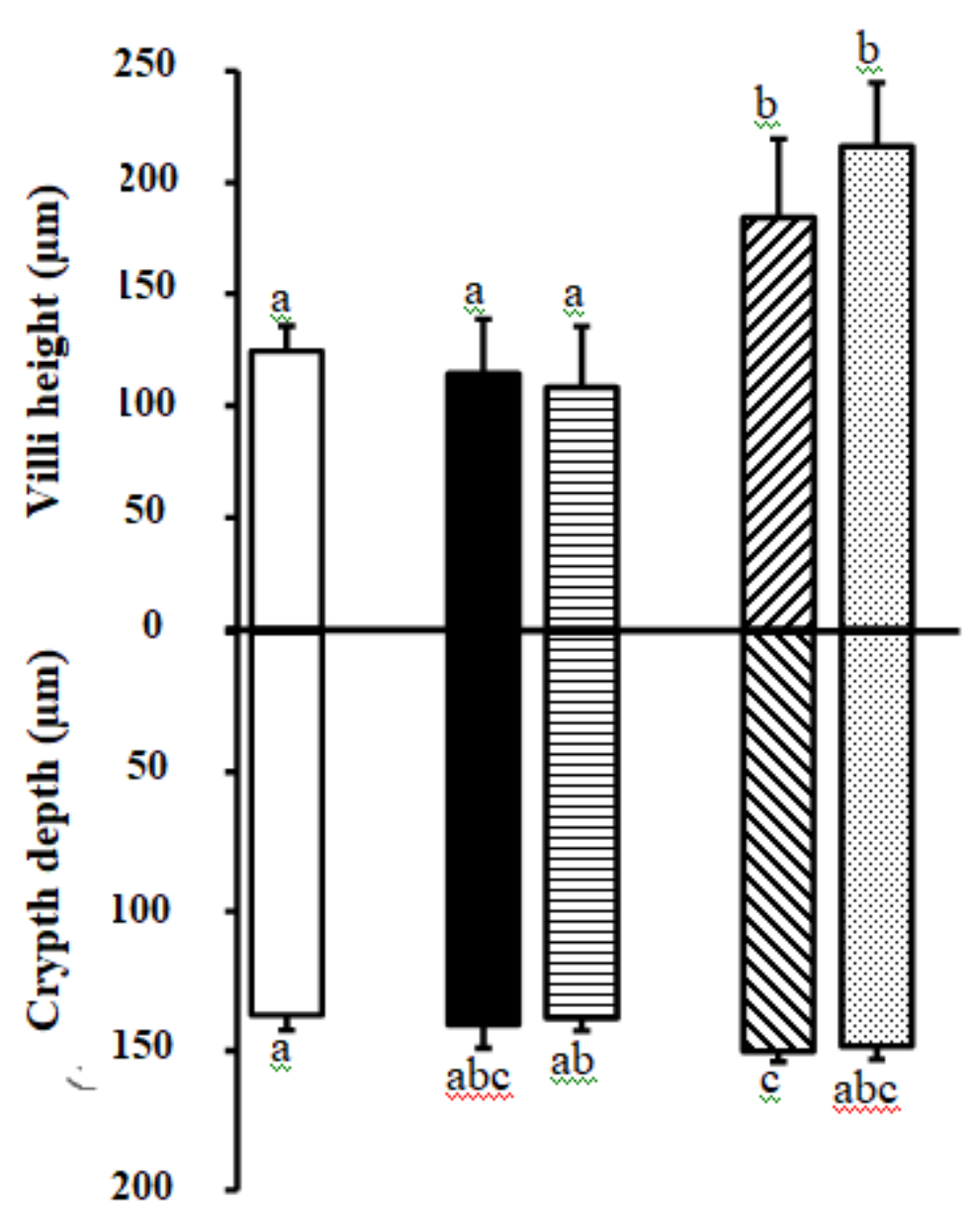

Figure 2. Effects of heat-inactivated L. plantarum and the culture supernatant exposure on villi height and crypt depth of jejunal explants of pigs. Values are mean height and depth $(\mu \mathrm{m})$. Values are means with standard deviation of the mean represented by vertical bars (n 6 animals). Mean values with unlike letters were significantly different $(\mathrm{p} \leq 0.05)$. Tukey test. Control( $\square)$. LP1-heat-inactivated L. plantarum strain 1 (匹), LP2-heat-inactivated L. plantarumstrain 2 (目), CS1- culture supernatant of heat-inactivated $L$. plantarum strain $1(\mathbb{G}), \mathrm{CS} 2$ - culture supernatant of heat-inactivated L. plantarum strain 2 (国).

LAB have been suggested to be an alternative strategy to antibiotic growth promoters and, many species of these bacteria are promising natural alternatives to chemical preservatives in food and feed (Meng et al., 2010). Nevertheless, additional research still to be performed on the effects of LAB on intestinal morphology, since few studies have focused on this aspect. Most of the available data have reported the effects of LAB on performance parameters or in the interaction of intestinal pathogens (Yang, $2015 \mathrm{~b}$ ). In addition, it remains to be investigated if cell-free supernatants of LAB are toxic to animals and humans. In the present study, we have used two strains of $L$. plantarum heat inactivated and their culture supernatant on piglets jejunal explants in order to determine if they have an effect on jejunal morphology. We have observed that the exposure of jejunal explants to heat inactivated L. plantarum strains induced moderate toxic effects, whereas the exposure to their culture supernatants improved the intestinal morphology. Nevertheless, a morphological improvement trend was achieved in explants treated with LP2 when comparing to LP1 treated explants. Since LP2 was a wild strain, this difference could be implicated to the ecological niche and environmental condition of the bacteria. 


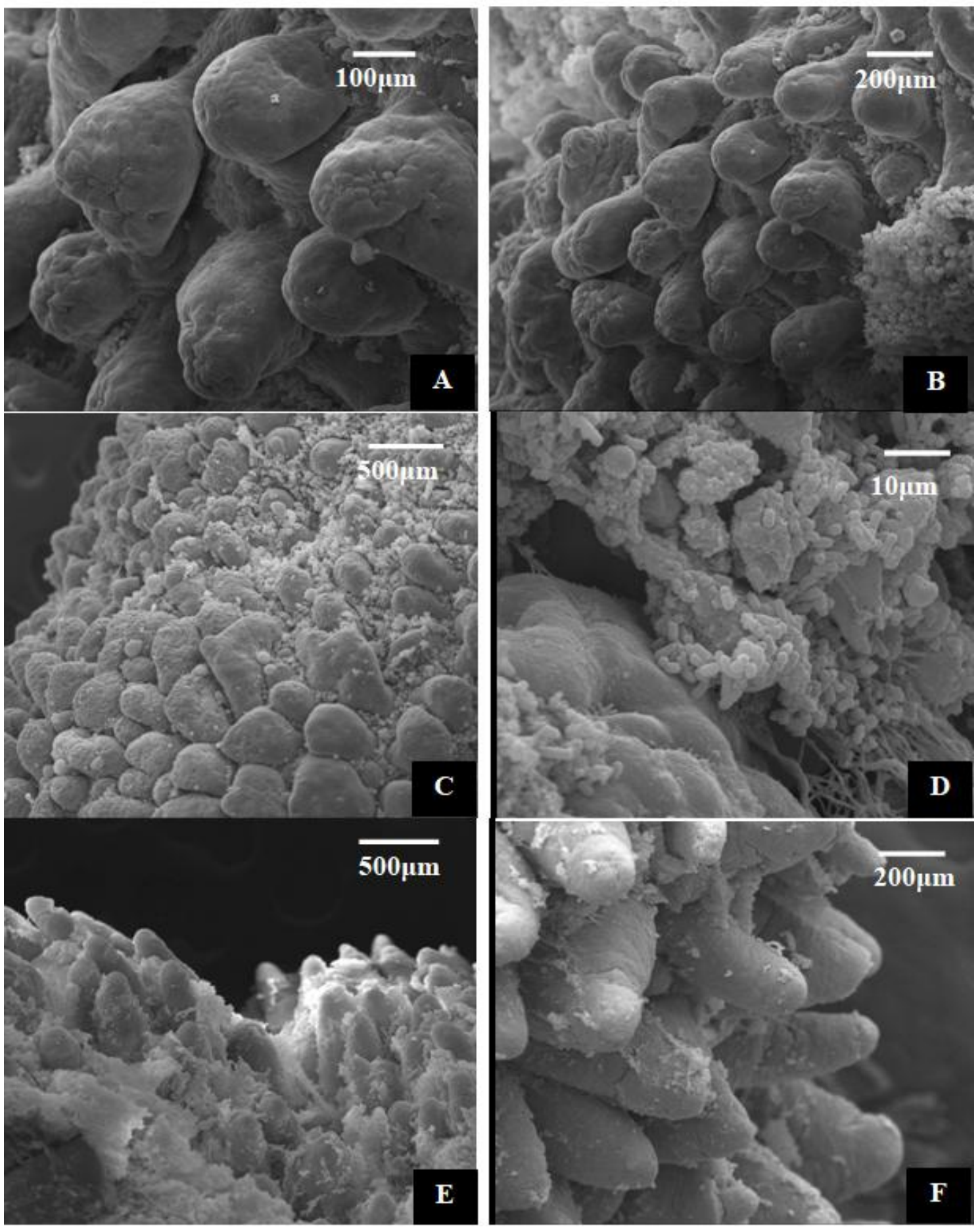

Figure 3. Morphological effects of heat-inactivated L. plantarum and the culture supernatant exposure on pigs jejunal explants in scanning electron microscopy assessment. Explants of jejunum of a 24 days old piglet. Normal jejunum as seen by scanning electron microscopy from a piglet of 24 days old. x 800 . Bar $100 \mu \mathrm{m}$ (A). A low magnification survey picture of the tissue shows numerous leaf and finger shaped villi of normal sizes and shapes. x 200. Bar $200 \mu \mathrm{m}$ (B). Villi of explants treated with LP1 with mild atrophy. x

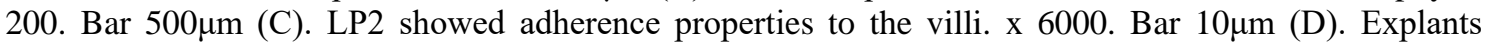

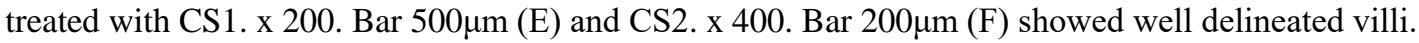


The toxic effects were verified by a significant decrease in the morphological score $(20 \%$ for LP1 and $17 \%$ for LP2) represented by changes such as villi atrophy, enterocyte flattening, and necrosis compared to the control explants. Interestingly, the mean villi height and crypt depth of these groups remained similar to untreated explants. Both strains of heat inactivated $L$. plantarum retained the ability to adhere to enterocytes as demonstrated by scanning electron microscopy analysis. Enterocyte adherence and competition binding for mannosylated receptors are described as strategies of $L$. plantarum to reduce the number of pathogenic bacteria in the intestine (De Vries et al., 2006). In the present study, bacteria adherence showed no positive effect, since villi atrophy is clearly evident by the SEM assay. By contrast, the majority of the in vivo or in vitro studies report beneficial effects following the ingestion or exposure to different strains of $L$. plantarum. These effects include intestinal immune stimulation (modulating cytokines expression) (Matsuguchi et al., 2003), reduction in oxidative stress and elimination of pathogens (Paszti-Gere et al., 2012). In pigs, L. plantarum added to the diet showed beneficial effects as modulation of inflammatory response and increase in zootechnical parameters and meat quality (Suo et al., 2012, Hulst et al., 2015). To the best of authors' knowledge, it is the first study using an ex vivo model that focused on the histological aspects of healthy intestinal samples exposed to L. plantarum.

In this study, the histological aspects of the explants untreated and those exposed to the culture supernatants were similar. These mild histological changes are expected to occur in the ex vivo model as a consequence of a relative status of hypoxia (Basso et al., 2013). However, a significant increase in villi height was observed in explants exposed to both culture supernatants (1.5-fold for strain 1 and 1.7 for strain 2) when compared to the control group. Also, a significant increase (1.1-fold) in crypt depth was verified in explants treated with strain 1 supernatant and a tendency to increase with CS2. As for other parameters, culture supernatants improved intestinal morphology. Increased villi height and crypt depth result in a rise in nutrient absorption and intestinal homeostasis. When compared to explants exposed to heat inactivated L. plantarum an improvement in the histological parameters were verified. This improvement is mainly associated with a reduction in the villi atrophy and apical necrosis. In the ultrastructural analysis, besides these aspects we also observed an increase in the amount of mucus covering enterocytes. Similar aspects were reported in HT-29 cells treated with cell-free supernatant of L. plantarum 299v. The treated cells presented an increased expression of the MUC2 and MUC3 genes and the stimulation of mucin production (Mack, 1999).

A possible mechanism for the improvement induced by the culture supernatants could involve the production of soluble bioactive factors released by $L$. plantarum during culture process (Yang, 2015a), which are capable of eliciting responses in epithelial cells, triggering activation of various cell signaling pathways that led to intestinal homeostasis (Rao and Samak, 2013). Culture supernatant of L. plantarum 2142 downregulated significantly the expression of proinflammatory cytokines IL- 8 and $\mathrm{TNF}-\alpha$ and simultaneously increased the Hsp70 level in IPEC cells. The authors hypothesized that these effects are associated with the production of small peptides by this strain of lactobacillus (Paszti-Gere et al., 2012).

\section{CONCLUSIONS}

Taken together these results indicate that culture supernatants from $L$. plantarum promote enhancement in intestinal morphology contributing with intestinal homeostasis.

\section{ACKNOWLEGMENTS}

LM and APFRLB are supported by a CNPq fellowship. JG is supported by a Capes/Fundação Araucária fellowship. Authors thank to Electronic Microscopy Laboratory and Microanalysis, UEL/SETI. 


\section{REFERENCES}

ADAMS, C.A. The probiotic paradox: live and dead cells are biological response modifiers. Nutr. Res. Rev., v.23, p.37-46, 2010.

BASSO, K.; GOMES, F.; BRACARENSE, A.P. Deoxynivanelol and fumonisin, alone or in combination, induce changes on intestinal junction complexes and in E-cadherin expression. Toxins v.5, p.2341-2352, 2013.

CHUANG, L.; WU, K.G.; PAI, C. et al. Heatkilled cells of lactobacilli skew the immune response toward $\mathrm{T}$ helper 1 polarization in mouse splenocytes and dendritic cell-treated T cells. $J$. Agric. Food Chem., v.55, p.11080-11086, 2007.

DE VRIES, M.C.; VAUGHAN, E.E.; KLEEREBEZEM, M.; VOS, W.M. Lactobacillus plantarum - survival, functional and potential probiotic properties in the human intestinal tract. Int Dairy J., v.16, p.1018-1028, 2006.

EWASCHUK, J.B.; WALKER, J.W.; DIAZ, H.; MADSEN, K.L. Bioproduction of conjugated linoleic acid by probiotic bacteria occurs in vitro and in vivo in mice. J. Nutr., v.136, p.1483-1487, 2006.

FRANCO, T.S.; GARCIA, S.; HIROOKA, E.Y.; ONO, Y.S.; SANTOS, J.S. Lactic acid bacteria in the inhibition of Fusarium graminearum and deoxynivalenol detoxification. J. Appl. Microbiol., v.111, p.739-748, 2011.

WORLD HEALTH ORGANIZATION EXPERT CONSULTATION AND FOOD AND AGRICULTURE ORGANIZATION. Evaluation of health and nutritional properties of powder milk and live lactic acid bacteria. Córdoba, Argentina, 2001.

FUJIWARA, D.; INOUE, S.; WAKABAYASHI, H.; FUJII, T. The anti-allergic effects of lactic acid bacteria are strain dependent and mediated by effects on both Th1/Th2 cytokine expression and balance. Int. Arch. Allergy Immunol., v.135, p.205-215, 2004.

FUJIYA, M.; MUSCH, M.W.; NAKAGAWA, Y. et al. The Bacillus subtilis quorum-sensing molecule CSF contributes to intestinal homeostasis via OCTN2, a host cell membrane transporter. Cell Host Microbe, v.1, p.299-308, 2007.
HULST, M.; GROSS, G.; LIU, Y. et al. Oral administration of Lactobacillus plantarum 299v modulates gene expression in the ileum of pigs: prediction of crosstalk between intestinal immune cells and sub-mucosal adipocytes. Genes Nutr., v.10, p.1-13, 2015.

KANASUGI, H.; HASEGAWA, T.; GOTO, Y. et al. Single administration of enterococcal preparation (FK-23) augments non-specific immune responses in healthy dogs. Int. J. Immunopharmacol., v.19, p.655-659, 1997.

LEE, J.; YUN, H.S.; CHO, K.W. et al. Evaluation of probiotic characteristics of newly isolated Lactobacillus spp.: immune modulation and longevity. Int. J. Food Microbiol., v.148, p.80-86, 2011.

MACK, D.R.; MICHAIL, S.; WEI, S.; MCDOUGALL, L.; HOLLINGSWORTH, M.A. Probiotics inhibit enteropathogenic E. coli adherence in vitro by inducing intestinal mucin gene expression. Am. J. Physiol., v.276, part.1, p.G941-G950, 1999.

MAIDANA, L.; GEREZ, J.R.; EL KHOURY, R. et al. Effects of patulin and ascladiol on porcine intestinal mucosa: an ex vivo approach. Food Chem. Toxicol., v.98, part.B, p.189-194, 2016.

MATSUGUCHI, T.; TAKAGI, A.; MATSUZAKI, T. et al. Lipoteichoic acids from Lactobacillus strains elicit strong tumor necrosis factor alphainducing activities in macrophages through Tolllike receptor 2. Clin. Diagn. Lab. Immunol., v.10, p.259-266, 2003.

MATSUMOTO, M.; KURIHARA, S.; KIBE, R.; ASHIDA, H.; BENNO, Y. Longevity in mice is promoted by probiotic-induced suppression of colonic senescence dependent on upregulation of gut bacterial polyamine production. PLoS One, v.6, p.e23652, 2011.

MEIMANDIPOUR, A.; SHUHAIMI, M.; SOLEIMANI, A.F. et al. Selected microbial groups and short-chain fatty acids profile in a simulated chicken cecum supplemented with two strains of Lactobacillus. Poult. Sci., v.89, p.470476, 2010.

MENG, Q.W.; YAN, L.; AO, X. et al. Influence of probiotics in different energy and nutrient density diets on growth performance, nutrient digestibility, meat quality, and blood characteristics in growing-finishing pigs. $J$. Anim. Sci., v.88, p.3320-3326, 2010. 
PASZTI-GERE, E.; SZEKER, K.; CSIBRIKNEMETH, E. et al. Metabolites of Lactobacillus plantarum 2142 prevent oxidative stress-induced overexpression of proinflammatory cytokines in IPEC-J2 cell line. Inflammation, v.35, p.14871499, 2012.

PRIYAMVADA, S.; ANBAZHAGAN, A.N.; KUMAR, A. et al. Lactobacillus acidophilus stimulates intestinal P-glycoprotein expression via a c-Fos/c-Jun-dependent mechanism in intestinal epithelial cells. Am. J. Physiol. Gastrointest. Liver Physiol., v.310, p.G599G608, 2016.

RAO, R.K.; SAMAK, G. Protection and restitution of gut barrier by probiotics: nutritional and clinical implications. Curr. Nutr. Food Sci., v.9, p.99-107, 2013.

SAKAI, Y.; TSUKAHARA, T.; BUKAWA, W.; MATSUBARA, N.; USHIDA, K. Cell preparation of Enterococcus faecalis strain EC12 prevents vancomycin-resistant enterococci colonization in the cecum of newly hatched chicks. Poult. Sci., v.85, p.273-277, 2006.

SALISBURY, J.G.; NICHOLLS, T.J.; LAMMERDING, A.M.; TURNIDGE, J.; NUNN, M.J. A risk analysis framework for the long-term management of antibiotic resistance in food-producing animals. Int. J. Antimicrob. Agents, v.20, p.153-164, 2002.

SASHIHARA, T.; SUEKI, N.; IKEGAMI, S. An analysis of the effectiveness of heat-killed lactic acid bacteria in alleviating allergic diseases. $J$. Dairy Sci., v.89, p.2846-2855, 2006.

SEGAWA, S.; FUJIYA, M.; KONISHI, H. et al. Probiotic-derived polyphosphate enhances the epithelial barrier function and maintains intestinal homeostasis through integrin-p38 MAPK pathway. PLoS One, v.6, p.e23278, 2011.
SHAHIN, A.A.M. Removal of aflatoxin $B_{1}$ from contaminated liquid media by dairy lactic acid bacteria. Intern. J. Agric. Biol., v.9, p.71-75, 2007.

SUO, C.; YIN, Y.; WANG, X. et al. Effects of lactobacillus plantarum ZJ316 on pig growth and pork quality. BMC Vet. Res., v.8, p.1-12, 2012.

THACKER, P.A. Alternatives to antibiotics as growth promoters for use in swine production: a review. J. Anim. Sci. Biotechnol., v.4, p.35, 2013.

WITTE, W. Selective pressure by antibiotic use in livestock. Int. J. Antimicrob. Agents, v.16, Suppl.1, p.S19-S24, 2000.

YAN, F.; CAO, H.; COVER, T.L. et al. Soluble proteins produced by probiotic bacteria regulate intestinal epithelial cell survival and growth. Gastroenterology, v.132, p.562-575, 2007.

YANG, F.; HOU, C.; ZENG, X.; QIAO, S. The use of lactic acid bacteria as a probiotic in swine diets. Pathogens, v.4, p.34-45, 2015 b.

YANG, F.; WANG, A.; ZENG, X. et al. Lactobacillus reuteri $\mathrm{I} 5007$ modulates tight junction protein expression in IPEC-J2 cells with LPS stimulation and in newborn piglets under normal conditions. BMC Microbiol., v.15, p.32, $2015 \mathrm{a}$.

YEN, H.C.; LAI, W.K.; LIN, C.S.; CHIANG, S.H. Medium-chain triglyceride as an alternative of in-feed colistin sulfate to improve growth performance and intestinal microbial environment in newly weaned pigs. Anim. Sci. J., v.86, p.99-104, 2015. 